\title{
KEPUASAN KONSUMEN TERHADAP ATRIBUT SAYURAN HIDROPONIK CASA FARM BANDUNG
}

\section{CUSTOMER SATISFACTION WITH CASA FARM BANDUNG HYDROPONIC VEGETABLE ATTRIBUTES}

\author{
Irfan Nasrulloh*, Trisna Insan Noor \\ Universitas Padjadjaran, Jl. Raya Bandung Sumedang KM. 21 \\ *E-mail: Irfan.nasrulloh99@gmail.com \\ (Diterima 09-02-2021; Disetujui 03-06-2021)
}

\begin{abstract}
ABSTRAK
Sayuran merupakan salah satu komoditas unggulan karena memiliki nilai ekonomis yang tinggi. Selain itu, konsumsi sayur diperlukan tubuh sebagai salah satu sumber vitamin, mineral dan serat dalam mencapai pola makan sehat sesuai anjuran pedoman gizi seimbang untuk mendapatkan kesehatan yang optimal. Casa Farm Hidroponik merupakan salah satu produsen sayuran hidroponik asal Kota Bandung yang sudah berdiri sejak tahun 2014. Pelayanan menjadi fakor yang sangat penting untuk diperhatikan dalam menghadapi persaingan, karena pelayanan yang kurang maksimal dapat mengurangi jumlah konsumen. Oleh karena itu, peningkatan kualitas pelayanan diperlukan dalam upaya menarik konsumen untuk membeli sayuran di Casa Farm Hidroponik. Penelitian ini dilakukan dengan menyebarkan 35 kuesioner dan dilakukan perhitungan dengan metode Importance Performance Analysis (IPA) dan metode Customer Satisfaction Index (CSI). Metode IPA bertujuan untuk mengetahui nilai tingkat kepentingan dan tingkat kinerja dari atribut sayuran hidroponik Casa Farm, Dilanjutkan pada metode CSI yang bertujuan untuk mengetahui tingkat kepuasan pelanggan secara menyeluruh. Dari hasil perhitungan metode IPA pada Diagram Kartesius dari 13 atribut terdapat 5 atribut yang memerlukan perbaikan dan peningkatan yaitu atribut nomor 7, 9, 10,11, dan 13. Hasil perhitungan metode CSI pada atribut sayuran hidroponik Casa Farm mendapatkan skor sebesar $89 \%$, skor tersebut berada dalam suatu rentang skala $81 \%<$ CSI $\leq 100 \%$ yang berarti bahwa tingkat kepuasan konsumen responden termasuk dalam kategori sangat puas.
\end{abstract}

Kata Kunci: Sayur, Hidroponik, Pelayanan, Importance and Performance Analysis (IPA), Customer Satisfaction Index (CSI)

\section{ABSTRACT}

Vegetables is one of the leading commodities because it has high economic value. Vegetable consumption is needed by the body as one of the sources of vitamins, minerals and fiber in achieving a healthy diet in accordance with the recommendations of balanced nutrition guidelines to obtain optimal health. Casa Farm Hydroponics is one of the producers of hydroponic vegetables from Bandung that has been established since 2014. In the face of competition for services becomes a very important things, because the service that is not maximal can reduce the number of consumers. Therefore, improved service quality is needed in an effort to attract consumers to buy vegetables at Casa Farm Hydroponics. This research was conducted by distributing 35 questionnaires and carried out calculations by Importance Performance Analysis (IPA) method and Customer Satisfaction Index (CSI) method. IPA method aims to determine the value of interest level and performance level of Casa Farm hydroponic vegetable attributes. CSI method that aims to know the overall level of customer satisfaction. From the calculation of IPA method in Cartesian Diagram of 13 attributes there are 5 attributes that require improvement and improvement, namely attributes number 7, 9, 10, 11, and 13. The calculation result of CSI method in Casa Farm hydroponic vegetable attribute scored by $89 \%$, the score is in a scale range of $81 \%$ 
$<C S I \leq 100 \%$ which means that the respondent's consumer satisfaction level belongs to the category of very satisfied.

Keywords: Vegetable, Hydroponics, Service, Importance and Performance Analysis (IPA), Customer Satisfaction Index (CSI)

\section{PENDAHULUAN}

Indonesia merupakan salah satu negara yang dikenal dengan kekayaan sumber daya alamnya yang begitu melimpah. Menurut Tandiono (2018), Indonesia merupakan negara agraris yang memiliki potensi besar di sektor pertanian, hal ini menjadikan sektor pertanian memegang peranan penting dalam membangun perekonomian dan pemenuhan kebutuhan pangan penduduk Indonesia.

Salah satu jenis komoditas pertanian di Indonesia ialah tanaman sayuran yang merupakan salah satu komoditas unggulan karena memiliki nilai ekonomis yang tinggi. Selain itu, sayuran juga memiliki masa panen yang relatif pendek, permintaan pasarnya juga cukup tinggi karena sayuran merupakan kebutuhan sehari-hari (Setyaningrum dan Cahyo, 2012).

Menurut data Badan Ketahanan Pangan (BKP) tahun 2019, tingkat konsumsi masyarakat Indonesia terhadap sayuran pada tahun 2018 mengalami peningkatan. Oleh karena itu, perlu diiringi dengan peningkatan produksi sayuran pula agar nantinya setiap kebutuhan sayuran dapat terpenuhi.

Peningkatan produksi sayuran perlu didukung dengan berbagai usaha, salah satunya dengan pemanfaatan lahan non pertanian, salah satu contohnya ialah dengan menggunakan teknik hidroponik. Teknik hidroponik merupakan teknik bercocok tanam tanpa menggunakan tanah sebagai medianya, melainkan dapat menggunakan air atau bahan lainnya seperti kerikil, pecahan genteng, arang sekam, pasir, dan batu bata. Teknik produksi ini dapat berkembang secara cepat karena memiliki banyak kelebihan. Kelebihan yang utama ialah keberhasilan tanaman untuk tumbuh dan berproduksi akan lebih terjamin. Kelebihan lainnya adalah perawatan lebih praktis, penggunaan pupuk lebih hemat, tanaman dapat tumbuh dengan cepat dan tidak kotor, hasil produksi lebih kontinu, serta beberapa jenis tanaman dapat dibudidayakan di luar musim (Lingga, 2005).

Teknik hidroponik saat ini sudah mulai tersebar di berbagai daerah di Indonesia, salah satu perusahaan 
hidroponik ini adalah Casa Farm Bandung. Casa Farm merupakan salah satu perusahaan swasta asal bandung yang bergerak di sektor pertanian, khususnya budidaya secara hidroponik. Casa farm telah berdiri sejak 15 November 2014, dan sampai saat ini Casa Farm merupakan satu-satunya perusahaan di Bandung yang memiliki 3 jenis produk untuk ditawarkan kepada konsumen. Produk yang pertama adalah sayuran segar seperti kangkung, pakcoy, bayam, selada kriting, selada merah, dan beberapa jenis sayuran lainnya. Selanjutnya, Casa Farm juga menjual berbagai macam alat perlengkapan hidroponik seperti netpot, larutan nutrisi, stater kit hidroponik, dan masih banyak lagi; lalu jenis produk yang terakhir adalah kelas dasar hidroponik.

Proses penjualan produk-produk di Casa Farm saat ini dilakukan secara online maupun secara langsung sehingga memberikan kebebasan kepada konsumen untuk bisa memperoleh kebutuhannya. Namun, menurut pemilik Casa Farm Budi Haryana, penjualan sayuran segar saat ini mengalami penurunan dikarenakan pandemi Covid19 yang melanda Indonesia mengakibatkan kegiatan hotel, restoran, kafe terganggu; bahkan ada yang harus tutup, dimana selama ini kebanyakan konsumen sayuran segar Casa farm didominasi dari sektor tersebut. Menyadari hal tersebut membuat Casa Farm sadar akan perlunya mencari segmentasi konsumen lain, yaitu konsumen skala rumah tangga. Namun, untuk bisa memenangkan persaingan tentunya perusahaan harus berusaha untuk memberikan pelayanan dan kualitas produk sayuran sesuai dengan kebutuhan dan keinginan konsumen. Melalui penelitian ini, penulis bertujuan untuk mengetahui karakteristik konsumen, tingkat kepuasan konsumen terhadap produk, dan kinerja perusahaan yang sudah dirasakan serta menentukan atribut-atribut yang menjadi prioritas. Dengan menggunakan metode Customer Satisfaction Index (CSI) untuk mengetahui tingkat kepuasan konsumen terhadap atribut sayuran hidroponik dan metode Importance Performance Analisys (IPA) digunakan untuk mengidentifikasi tingkat kepentingan setiap atribut sayuran serta untuk mengetahui prioritas perbaikan yang harus dilakukan oleh Casa Farm Hidroponik. 


\section{METODE PENELITIAN}

Penelitian dilaksanakan pada bulan Desember 2020 di beberapa kecamatan di Kota Bandung, yaitu Antapani, Arcamanik, Mandala Jati, dan Cinambo. Lokasi ini dipilih secara sengaja disesuaikan dengan tempat tinggal para konsumen yang telah membeli sayuran di Casa Farm.

Penelitian didesain secara kuantitatif dengan metode survey deskriptif. Data yang digunakan adalah data primer dan data sekunder. Data primer merupakan data yang berasal dari pengisian kuesioner dan wawancara para responden. Sedangkan data sekunder merupakan data yang diperoleh dari studi literatur lainnya yang berhubungan dengan penelitian.

Populasi dalam penelitian yaitu konsumen skala rumah tangga yang pernah membeli sayuran hidroponik di Casa Farm Bandung. Teknik pengambilan sampel dilakukan dengan teknik sampel jenuh (sensus) yaitu metode penarikan sampel bila semua anggota populasi dijadikan sampel. Hal ini sering dilakukan apabila jumlah populasi kecil (Supriyanto dan Machfudz, 2010). Dalam penelitian ini sampel yang akan diambil adalah seluruh konsumen skala rumah tangga dari Casa Farm sepanjang tahun 2020 yang berjumlah 35 orang.

Teknik analisis data yang digunakan dalam penelitian ini adalah teknik analisis deskriptif dengan menggunakan pengukuran skala likert. Selain itu penelitian ini menggunakan importance performance analysis (IPA) dan customer satisfication index (CSI) digunakan untuk menganalisis preferensi rumah tangga terhadap atribut-atribut sayuran yang menjadi pertimbangan dalam membeli sayur.

\section{HASIL DAN PEMBAHASAN}

\section{A. Karakteristik Konsumen}

Karakteristik responden dalam penelitian ini menggambarkan profil subjek penelitian, karakteristik responden diidentifikasi berdasarkan jenis kelamin, usia, pekerjaan, pendapatan (per bulan), dan domisili tinggal. Responden yang dimaksud dalam penelitian ini adalah konsumen sayuran hidroponik Casa Farm skala rumah tangga di tahun 2020.

\section{Jenis Kelamin}

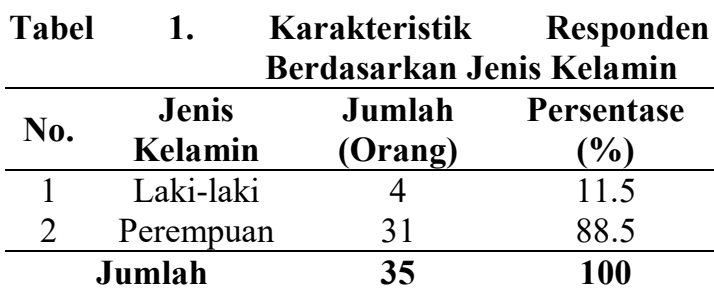

Tabel 1 menunjukan bahwa mayoritas kosumen adalah perempuan 
sebanyak 31 orang $(88.5 \%)$. Hal ini menunjukan bahwa perempuan memegang kendali untuk mengurus kebutuhan rumah tangga salah satunya ialah kebutuhan pemenuhan gizi keluarga. Hasil ini juga sejalan dengan penelitian yang dilakukan Juarwan (2013) yang menyatakan bahwa perempuan cenderung lebih berperan dalam mengambil keputusan rumah tangga terkait pembelian kebutuhan pokok seperti sayuran.

\section{Usia}

Kebutuhan dan kepentingan konsumen berubah seiring bertambahnya usia (Solomon, 2004). Oleh karena itu, penting bagi perusahaan untuk memahami usia konsumen. Menurut Al Amin (2017) dalam penelitiannya kelompok umur dibagi menjadi empat kelompok yaitu kanak-kanak (5-11 tahun), remaja (12-25 tahun), dewasa (26-45 tahun), dan lansia (46-65 tahun). Berikut merupakan karakteristik konsumen sayuran segar di Casa Farm (Tabel 2).

\begin{tabular}{|c|c|c|c|}
\hline Tabel & \multicolumn{3}{|c|}{$\begin{array}{l}\text { Karakteristik Responden } \\
\text { Berdasarkan Usia }\end{array}$} \\
\hline No. & $\begin{array}{c}\text { Kelompok } \\
\text { Usia }\end{array}$ & $\begin{array}{l}\text { Jumlah } \\
\text { (Orang) }\end{array}$ & $\begin{array}{c}\text { Persentase } \\
(\%) \\
\end{array}$ \\
\hline 1 & $\begin{array}{c}\text { Kanak- } \\
\text { kanak }\end{array}$ & 0 & 0 \\
\hline 2 & Remaja & 1 & 3 \\
\hline 3 & Dewasa & 27 & 77 \\
\hline 4 & Lansia & 7 & 20 \\
\hline & umlah & 35 & 100 \\
\hline
\end{tabular}

Berdasarkan Tabel 2, dapat dilihat bahwa mayoritas konsumen (77\%) sayuran segar di Casa Farm berada pada kelompok usia dewasa, dimana usia termuda konsumen 21 tahun dan usia tertua adalah 59 tahun. hal ini sejalan dengan hasil penelitian Hadianti (2019) yang menyatakan bahwa kebanyakan konsumen yang membeli sayuran hidroponik adalah kelompok usia produktif (16-64 tahun), hal ini disebabkan oleh faktor pengetahuan yang luas akan keunggulan dari sayuran hidroponik dan pentingnya melaksanakan pola hidup sehat.

\section{Pekerjaan}

\begin{tabular}{|c|c|c|c|}
\hline Tabel & \multicolumn{3}{|c|}{$\begin{array}{l}\text { 3. } \\
\text { Berdasarkarkan Pekerjaan } \\
\text { Berdik }\end{array}$} \\
\hline No. & $\begin{array}{c}\text { Jenis } \\
\text { Pekerjaan }\end{array}$ & $\begin{array}{l}\text { Jumlah } \\
\text { (Orang) }\end{array}$ & $\begin{array}{l}\text { Persentase } \\
(\%)\end{array}$ \\
\hline 1 & ASN & 4 & 11 \\
\hline 2 & Dokter Gigi & 1 & 3 \\
\hline 3 & $\begin{array}{l}\text { Ibu Rumah } \\
\text { Tangga }\end{array}$ & 22 & 63 \\
\hline 4 & $\begin{array}{l}\text { Karyawan } \\
\text { Swasta }\end{array}$ & 5 & 14 \\
\hline 5 & Mahasiswa & 1 & 3 \\
\hline 6 & Wiraswasta & 2 & 6 \\
\hline & Jumlah & 35 & 100 \\
\hline
\end{tabular}

Tabel 3 menunjukan bahwa status pekerjaan responden didominasi ibu rumah tangga dengan jumlah sebanyak 22 orang $(63 \%)$. Hal ini sejalan dengan hasil penelitian Savira \& Prihtanti (2019) yang menyatakan bahwa banyaknya konsumen sayuran hidroponik dari kalangan ibu rumah tangga dikarenakan 
kegiatan belanja merupakan sebuah pekejaan yang sudah lazim dan sangat melekat pada ibu rumah tangga. Selain itu, beragamnya status pekerjaan (6) dari responden juga sejalan dengan hasil penelitian Arbi (2016) yang menyatakan sayuran hidroponik diminati oleh berbagai kalangan dari berbagai macam jenis pekerjaan, dan khususnya bagi mereka yang sadar akan pentingnya kesehatan.

\section{Pendapatan (Per Bulan)}

Tabel 4. Karakteristik Responden Berdasarkan Pendapatan

\begin{tabular}{cccc}
\hline No & $\begin{array}{c}\text { Besar } \\
\text { Pendapatan } \\
\text { (Rupiah) }\end{array}$ & $\begin{array}{c}\text { Jumlah } \\
\text { (Orang) }\end{array}$ & $\begin{array}{c}\text { Persentase } \\
(\%)\end{array}$ \\
\hline 1 & $\begin{array}{c}\text { Kurang dari 1 } \\
\text { Juta }\end{array}$ & 5 & 14,3 \\
2 & 1-3 Juta & 5 & 14,3 \\
3 & Diatas 3 Juta & 25 & 71,4 \\
\hline & Total & $\mathbf{3 5}$ & $\mathbf{1 0 0}$ \\
\hline
\end{tabular}

Tabel 4 menunjukan bahwa mayoritas konsumen sayuran hidroponik di Casa Farm memiliki rata-rata pendapatan per bulannya di atas 3 juta rupiah. Hal ini menunjukan mayoritas konsumen berada pada keadaan mampu. Hal ini sejalan dengan pendapat Suhardi (2016) yang menyatakan bahwa pendapatan berpengaruh terhadap permintaan sayuran hidroponik. responden yang pendapatan keluarganya tinggi, cenderung melakukan pembelian sayuran hidroponik dengan jumlah yang tinggi juga.

\section{Domisili Tinggal}

Tabel 5. Karakteristik Responden Berdasarkan Domisili

\begin{tabular}{lccc}
\hline No. & $\begin{array}{c}\text { Domisili } \\
\text { Tinggal }\end{array}$ & $\begin{array}{c}\text { Jumlah } \\
\text { (Orang) }\end{array}$ & $\begin{array}{c}\text { Persentase } \\
\mathbf{( \% )}\end{array}$ \\
\hline 1 & $\begin{array}{c}\text { Kota } \\
\text { Bandung }\end{array}$ & 35 & 100 \\
& & $\mathbf{3 5}$ & $\mathbf{1 0 0}$ \\
\hline
\end{tabular}

Domisili para responden konsumen sayuran hidroponik Casa Farm yang didapatkan dari kuesioner menunjukan hasil yang seragam dimana data menunjukan seluruh konsumen (100\%) berdomisili di Kota Bandung.

\section{B. Analisis Tingkat Kepentingan dan Kinerja (Importance Performance Analysis) Atribut Sayuran Hidroponik Segar}

\section{Menganalisis Posisi Atribut dalam Matriks IPA}

Matriks IPA merupakan matriks yang berupa diagram kartesius, dibatasi oleh dua buah garis yang berpotongan tegak lurus pada suatu titik $\left(\mathrm{X}^{\bar{y}}, \mathrm{Y} \overline{\overline{)}}\right.$. Metode IPA dilakukan untuk mengetahui apakah atribut sayuran hidroponik segar yang diteliti memiliki nilai tingkat kepentingan dan tingkat kinerja sesuai dengan harapan konsumen. Berikut skor kepentingan dan tingkat kinerja dari 13 atribut sayuran yang dinilai oleh para responden (Tabel 6). 
Tabel 6. Nilai Rata-rata Atribut Sayuran Hidroponik Berdasarkan Tingkat Kepentingan dan Tingkat Kinerja

\begin{tabular}{|c|c|c|}
\hline No $\quad$ Atribut & Importance & Performance \\
\hline Mutu Produk & 4,67 & 4,62 \\
\hline $\begin{array}{ll}\text { 1. } & \begin{array}{l}\text { Sayuran } \\
\text { higienis }\end{array} \\
\text { bebas } \\
\text { pestisida }\end{array}$ & 4,71 & 4,74 \\
\hline $\begin{array}{l}\text { 2. Kesegaran } \\
\text { sayuran }\end{array}$ & 4,89 & 4,74 \\
\hline $\begin{array}{l}\text { 3. Sayuran } \\
\text { mulus } \\
\text { tanpa cacat } \\
\text { serangan } \\
\text { hama }\end{array}$ & 4,49 & 4,6 \\
\hline $\begin{array}{l}\text { 4. Sayuran } \\
\text { tidak rusak } \\
\text { atau busuk }\end{array}$ & 4,77 & 4,51 \\
\hline $\begin{array}{ll}\text { 5. } & \text { Sayuran } \\
\text { memiliki } \\
\text { rasa yang } \\
\text { enak }\end{array}$ & 4,51 & 4,54 \\
\hline Ciri Produk & 4,4 & 4,45 \\
\hline $\begin{array}{ll}\text { 6. } & \text { Tekstur } \\
\text { sayuran }\end{array}$ & 4,4 & 4,46 \\
\hline $\begin{array}{l}\text { 7. Keasrian } \\
\text { sayuran }\end{array}$ & 4,26 & 4,4 \\
\hline $\begin{array}{l}\text { 8. Kondisi } \\
\text { fisik } \\
\text { sayuran }\end{array}$ & 4,57 & 4,51 \\
\hline $\begin{array}{c}\text { Desain dan } \\
\text { Kemasan } \\
\text { Produk } \\
\end{array}$ & 4,14 & 4,36 \\
\hline $\begin{array}{ll}\text { 9. } & \text { Fungsi } \\
\text { kemasan } \\
\text { sayuran }\end{array}$ & 4,14 & 4,37 \\
\hline $\begin{array}{l}\text { 10. Penataan } \\
\text { sayuran }\end{array}$ & 4,11 & 4,31 \\
\hline $\begin{array}{l}\text { 11. Kerapian } \\
\text { kemasan }\end{array}$ & 4,17 & 4,4 \\
\hline Harga Produk & 4,14 & 3,9 \\
\hline $\begin{array}{l}\text { 12. Kelayakan } \\
\text { Harga }\end{array}$ & 4,23 & 4,49 \\
\hline $\begin{array}{l}\text { 13. Adanya } \\
\text { promo atau } \\
\text { diskon }\end{array}$ & 4,06 & 3,31 \\
\hline Jumlah & 57,3 & 57,4 \\
\hline Rata-rata $(\overline{\bar{X}}, \overline{\bar{Y}})$ & 4,41 & 4,42 \\
\hline
\end{tabular}

Berdasarkan Tabel 6, dapat dilihat bahwa pada total kolom kepentingan (importance) nilai atribut ada di angka 57,3 dan untuk total kolom kinerja adalah
57,4. Dapat disimpulkan bahwa secara keseluruhan kinerja porduk sayuran hidroponik segar Casa Farm sudah melebihi harapan para konsumen. Namun bila dilihat pada masing-masing atribut sayuran masih ada kineja atribut yang berada di bawah harapan konsumen, hal ini mengindikasikan perlu diadakannya peningkatan kinerja yaitu pada atribut mutu produk dan harga produk.

Nilai rata-rata tingkat kepentingan 13 atribut sayuran hidroponik segar adalah 4,41 dan nilai rata-rata tingkat kinerja adalah 4,42. Kedua nilai ini akan menjadi garis tengah pada diagram kartesius IPA sehingga diagram kartesius akan terbagi menjadi empat kuadran. Berikut adalah posisi atribut sayuran hidroponik segar yang dilihat dari 13 parameter yang ada dalam diagram kartesius IPA.

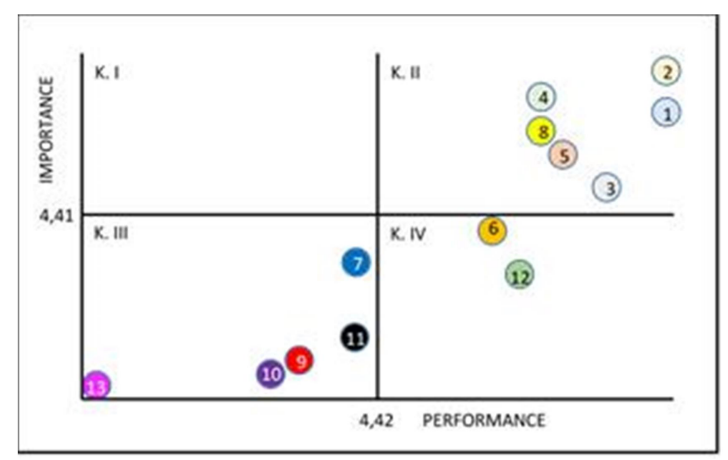

Gambar 1. Diagram Kartesius Important Performance Analysis Atribut Sayuran Hidroponik 
Pemetaan pada diagram kartesius yang berdasarkan tingkat kepentingan dan tingkat kinerja dapat memudahkan pihak terkait untuk melakukan perbaikan atribut yang dianggap sangat penting oleh konsumen. Perbaikan atribut tergantung pada posisi masing-masing atribut dalam keempat kuadran. Hasil analisis berupa posisi masing-masing atribut pada empat kuadran adalah sebagai berikut:

\section{Kuadran I}

Kuadran I diagram kartesius IPA menunjukkan bahwa tingkat kepentingan dari atribut dianggap sangat penting bagi konsumen, namun tingkat kinerjanya masih dirasa kurang memuaskan. Berdasarkan pada Gambar 1, menunjukkan tidak terdapat atribut pada kuadran I. Sehingga hal ini mengindikasikan atribut yang dirasa sangat penting bagi konsumen sudah penuhi oleh Casa Farm.

\section{Kuadran II}

Kuadran II diagram kartesius IPA menunjukkan bahwa tingkat kepentingan suatu atribut dinilai penting bagi konsumen dan tingkat kinerja pada atribut sayuran hidroponik sudah memuaskan. Dengan demikian, atribut yang berada pada kuadran ini harus dipertahankan kinerjanya. Atribut tersebut ialah:

\section{1) Sayuran Higienis Bebas Pestisida}

Berdasarkan Gambar 1, dapat dilihat bahwa atribut sayuran higienis bebas pestisida dinilai penting bagi konsumen responden, hal ini ditunjukan dengan nilai kepentingannya $(4,71)$ yang berada di atas nilai rata-rata kepentingan atribut sayuran hidroponik scara keseluruhan $(4,41)$. Bila dilihat dari sisi kinerja atribut ini dinilai sudah memuaskan bagi para konsumen responden, hal ini ditunjukan dari nilai kinerjanya $(4,74)$ yang lebih besar dari nilai rata-rata kepentingannya.

Pentingnya atribut ini juga sejalan dengan pernyataan Rizkiansah (2018) pada penelitiannya yang menyatakan bahwa seiring berkembangnya pendidikan dan teknologi, pola hidup masyarakat lebih mengutamakan kesehatan, sehingga permintaan sayuran hidroponik yang lebih higienis dan bebas pestisida terus meningkat. Selain itu, Budi Haryana sebagai pemiliki dari Casa Farm juga menuturkan perusahaannya sangat memperhatikan kebersihan produknya di masa pandemi Covid-19 saat ini, demi memberikan produk yang aman bagi konsumen.

\section{2) Kesegaran Sayuran}

Atribut kesegaran sayuran umumnya menjadi salah satu faktor 
utama bagi konsumen dalam membeli sayuran. Dari data yang diperoleh di lapangan bahwa kesegaran sayuran hidoponik dinilai sangat penting yaitu rata-rata nilai kepentingannya sebesar 4,89 , rata-rata nilai kepentingan atribut ini merupakan rata-rata nilai yang paling besar dibadingkan atribut-atribut lainnya. Hal ini menunjukan atribut kesegaran sayuran merupakan hal yang paling penting bagi konsumen responden. Pentingnya kesegaran sayuran ini juga sejalan dengan pernyataan Yasmin (2017) yang menyatakan bahwa kesegaran sayuran merupakan komponen terpenting karena layak atau tidaknya sayuran dapat dilihat dari kesegarannya.

Kinerja untuk atribut kesegaran juga dinilai sudah baik yaitu dengan ratarata nilai 4,74 , angka ini sama dengan rata-rata nilai atribut higienisitas sayuran yang mana merupakan rata-rata nilai tertinggi dibandingkan rata-rata nilai kinerja atribut lainnya. Oleh karena itu, kinerja atribut kesegaran sayuran ini perlu dipertahankan.

\section{3) Sayuran Mulus Tanpa Cacat Serangan Hama}

Atribut sayuran mulus tanpa cacat serangan hama dianggap penting bagi konsumen responden, hal ini ditunjukan dari rata-rata nilai kepentingan yang didapat yaitu 4,49 dimana angka ini masih lebih besar dibandingkan rata-rata nilai kepentingan keseluruhan $(4,41)$. Kinerja pada atribut ini juga dinilai sudah memuaskan, dapat dilihat dari rata-rata nilai kinerjanya yaitu 4,6. Hal ini sejalan dengan pernyataan Haryoto (2009) yang menyatakan bahwa sayuran hidroponik memiliki tingkat resiko serangan hama penyakit yang kecil dikarenakan media tanamnya steril.

\section{4) Sayuran Tidak Rusak atau Busuk}

Berdasarkan Gambar 1, dapat dilihat bahwa atribut Sayuran tidak rusak atau busuk dinilai penting dan harus dipertahankan kinerjanya, hal ini ditunjukan dari rata-rata nilai kepentingan $(4,77)$ dan kinerjanya $(4,51)$ yang lebih tinggi dari rata-rata nilai atribut secara keseluruhan. Selain itu atribut ini dirasa penting mengingat sayuran hidroponik sudah seharusnya memberikan produk yang lebih baik dibandingkan sayuran konvensional, sebagaimana yang diungkapkan Darmawan (2017) bahwa sayuran hidroponik dijual dengan harga yang lebih tinggi karena menawarkan kualitas yang lebih baik kepada konsumen.

\section{5) Sayuran Memiliki Rasa yang Enak}

Atribut Sayuran memiliki rasa yang enak dinilai konsumen responden sebagai atribut yang penting, hal ini dapat dilihat 
dari rata-rata nilai kepentingannya yaitu 4,51, nilai ini lebih besar dibandingkan rata-rata nilai kepentingan keseluruhan. Dari sisi kinerja atribut ini dinilai baik dimana rata-rata nilai kinerja sebesar 4,54 , yang artinya rasa dari sayuran yang diberikan sudah memuaskan konsumen dan harus dipertahankan. Hal ini sejalan dengan pernyataan Haryoto (2009) yang menyatakan terdapat beberapa kelebihan pada system hidroponik salah satunya memiliki rasa yang lebih enak sehingga nilai jualnya tinggi.

\section{6) Kondisi Fisik Sayuran}

Kondisi fisik sayuran hidroponik dapat dilihat dari keadaan akar, batang, dan daun. Berdasarkan hasil penelitian atribut ini memiliki rata-rata nilai kepentingan di atas rata-rata nilai keseluruhan yaitu 4,57, hal ini menandakan bahwa kondisi fisik sayuran merupakan atribut yang penting bagi para konsumen. Konsumen responden juga menilai kinerja atribut ini sudah memuaskan, hal ini dapat dilihat dari rata-rata nilai kinerjanya $(4,51)$ yang melebihi rata-rata nilai kinerja keseluruhan. Hal ini sejalan dengan pernyataan Purbajanti (2017) yang menyatakan bahwa penyediaan hara pada sistem hidroponik lebih optimal sehingga kondisi fisik tanaman yang dihasilkan lebih tinggi.

\section{Kuadran III}

Kuadran III diagram kartesius IPA menunjukkan atribut-atribut dengan tingkat kepentingan yang dianggap konsumen kurang penting dan tingkat kinerjanya pun biasa saja. Perbaikan terhadap atribut-atribut yang berada di kuadran ini memiliki prioritas yang rendah karena pengaruhnya terhadap manfaat yang dirasakan konsumen kecil. Atribut-atribut yang termasuk ke dalam kuadran III ini adalah keasrian sayuran, fungsi kemasan sayuran, penataan sayuran, kerapian kemasan, dan adanya promo atau diskon.

\section{1) Keasrian Sayuran}

Berdasarkan hasil penelitian pada Gambar 1, nilai kepentingan atribut keasrian sayuran $(4,26)$ jika dibandingkan dengan nilai rata-rata kepentingan seluruh atribut berada di bawah rata-rata $(4,42)$ sehingga atribut ini dirasakan kurang penting oleh konsumen responden. Untuk tingkat kinerja, nilai kinerja atribut keasrian sayuran $(4,4)$ juga berada di bawah nilai rata-rata kinerja seluruh atribut $(4,42)$ sehingga kinerjanya kurang dirasakan baik oleh konsumen responden. Hal ini menandakan atribut keasrian sayuran memiliki prioritas 
rendah bagi konsumen responden. Menurut konsumen responden, keasrian sayuran tidak terlalu penting dikarenakan sayuran hidroponik yang dibeli merupakan sayur untuk keperluan konsumsi.

\section{2) Fungsi Kemasan Sayuran}

Sebuah kemasan memiliki peran sebagai pelindung maupun identitas dari suatu produk dan memungkinkan memperkaya nilai suatu produk (Dermawan, 2017). Berdasarkan hasil penelitian dari 35 responden konsumen skala rumah tangga Casa Farm menilai atribut fungsi kemasan sayuran kurang penting, hal ini tergambar dari rata-rata nilai kepentingannya yang hanya 4,14 cukup rendah dibanding rata-rata nilai kepentingan keseluruhan. kinerja yang diberikan pada atribut fungsi kemasan sayuran juga dinilai belum baik, hal ini dapat dilihat dari rata-rata nilai kinerjanya $(4,37)$ yang masih di bawah rata-rata nilai kinerja keseluruhan $(4,42)$.

Hal ini sejalan dengan hasil penelitian Siregar (2019) yang menyatakan bahwa atribut kemasan masih diabaikan oleh konsumen karena mereka sudah tahu bahwa tanpa kemasan yang menarik sekalipun mereka tetap membeli sayuran tersebut, sebab mereka tahu manfaat serta kualitas produk yang ditawarkan sudah baik dan bagus. Namun, berbeda dengan hasil penelitian Mukhtar dan Nurif (2015) yang menyatakan bahwa kemasan atau packaging dapat meletakkan dan menyelamatkan bahkan menyimpan produk yang diproduksi, sehingga menjadi daya tarik tersendiri bagi konsumen.

\section{3) Penataan Sayuran}

Berdasarkan hasil penelitian pada Gambar 1, penataan sayuran memiliki rata-rata nilai kepentingan $(4,11)$ di bawah rata-rata nilai kepentingan keseluruhan $(4,41)$ sehingga atribut ini dinilai kurang penting oleh responden. Untuk rata-rata nilai kinerja atribut ini $(4,31)$ juga berada di bawah nilai rata-rata keseluruhan $(4,42)$ sehingga kinerjanya dinilai kurang baik. Hal ini tidak sejalan dengan penelitian Dhameria (2014) menyatakan bahwa penataan bertujuan untuk membantu meningkatkan penjualan, terutama melalui pembelian tak terencana yang dilakukan oleh konsumen. Namun menurut responden hal ini dirasa tidak terlalu penting karena sistem penjualan sayuran hidroponik Casa Farm dilakukan selama ini secara pre-order atau online. 


\section{4) Kerapian Kemasan}

Berdasarkan diagram kartesius (Gambar 1), atribut kerapian kemasan $(4,17)$ berada di bawah rata-rata nilai kepentingan keseluruhan $(4,41)$ sehingga atribut ini dapat dikatakan kurang penting bagi responden. Kinerja atribut kerapian kemasan juga dinilai belum baik, hal ini ditunjukan rata-rata nilai kinerjanya $(4,4)$ yang masih di bawah rata-rata nilai kinerja secara keseluruhan $(4,42)$. Hasil ini tidak sejalan dengan pernyataan Rizkiansah (2018) bahwa atribut kepedulian terhadap kemasan bernilai positif, artinya konsumen peduli dengan kemasan yang menarik, rapi, tidak rusak, menarik, dan informatif.

\section{5) Adanya Promo atau Diskon}

Berdasarkan hasil penelitian yang didapat, atribut ini dinilai kurang penting bagi responden, hal ini terlihat dari ratarata nilai kepentingannya $(4,06)$ yang berada di bawah rata-rata nilai kepentingan keseluruhan (4,41). Begitu pula untuk kinerja pada atribut ini juga dinilai belum baik, hal ini ditunjukan rata-rata nilai kinerjanya $(3,31)$ yang berada di bawah rata-rata nilai kinerja secara keseluruhan $(4,42)$. Atribut ini tidak menjadi priotitas bagi konsumen responden karena mayoritas konsumen responden berada pada kalangan menengah ke atas yang sudah mengetahui kelebihan dari sayuran hidroponik sehingga rela membayar lebih untuk itu. Hal ini sejalan dengan penelitian Yasmin (2017) yang menyatakan atribut harga berada pada prioritas terakhir bagi konsumen karena sebagian besar konsumen sudah mengetahui informasi tentang sayuran hidroponik yang lebih sehat apabila dikonsumsi karena bebas pestisida.

\section{Kuadran IV}

Kuadran IV diagram kartesius IPA menunjukkan atribut yang tingkat kepentingannya dinilai konsumen rendah, namun tingkat kinerja atribut tersebut dirasa tinggi oleh konsumen. Atribut yang termasuk ke dalam kuadran ini adalah tekstur sayuran dan kelayakan harga.

\section{1) Tekstur Sayuran}

Atribut tekstur sayuran dinilai kurang penting bagi konsumen responden. Hal ini ditunjukan rata-rata nilai kepentingannya $(4,4)$ yang berada di bawah rata-rata nilai kepentingan keseluruhan $(4,41)$. Namun, berdasarkan Gambar 1, dapat dilihat bahwa kinerja pada atribut ini memiliki rata-rata nilai kinerja $(4,46)$ di atas rata-rata nilai kinerja keseluruhan $(4,42)$, yang artinya kinerja yang diberikan pada atribut ini 
berlebihan. Hal ini tidak sejalan dengan hasil penelitian Andilla (2013) yang menyatakan bahwa dalam membeli sayuran konsumen akan melihat atribut tekstur sayuran sebagai atribut yang sangat penting dibanding atribut lainnya.

\section{2) Kelayakan Harga}

Berdasarkan Gambar 1, atribut kelayakan harga memiliki rata-rata nilai 4,23 dimana nilai ini masih berada di bawah rata-rata nilai kepentingan keseluruhan (4,41). sehingga dapat dikatakan bahwa atribut ini dinilai kurang penting bagi konsumen responden. Kinerja pada atribut ini memiliki rata-rata nilai $(4,49)$ yang berada di atas rata-rata nilai kinerja keseluruhan $(4,42)$, namun kinerja ini dinilai berlebihan mengingat atribut kelayakan harga yang bukan menjadi prioritas konsumen responden. Hal ini menandakan bahwa konsumen responden rela membayar lebih mahal untuk mendapatkan sayuran hidroponik, sebagaimana yang dikatakan pada hasil penelitian Yasmin (2017) bahwa konsumen sayuran hidroponik tidak begitu mementingkan atribut harga.

\section{Indeks Kepuasan Konsumen}

\section{(Customer Satisfaction Index)}

Kepuasan konsumen terhadap sayuran hidroponik pada penelitian ini dianalisis dengan menggunakan analisis
CSI. Perhitungan dalam CSI memperhitungkan nilai rata-rata kepentingan suatu atribut dalam menentukan tingkat kinerja atribut tersebut yang nantinya akan memberikan pengaruh terhadap tingkat kepuasan total konsumen responden. Hasil analisis ini akan menggambarkan tingkat kepuasan konsumen pada tahap sangat tidak puas, tidak puas, biasa atau netral, puas, dan sangat puas. Adapun perhitungan nilai CSI pada sayuran hidroponik dapat dilihat pada Tabel 7.

Perhitungan dalam analisis tersebut dimulai dengan cara menentukan weight factor yang telah diperoleh dari hasil pembagian antara nilai rata-rata kepentingan setiap atribut dengan total keseluruhan tingkat kepentingan atribut. Nilai weight factor berguna untuk menghitung nilai weight score. Nilai weight score itu sendiri didapat dari hasil perkalian antara weighted factor dengan nilai rata-rata kinerja tiap atribut atau disebut dengan mean satisfaction score (MSS). Nilai indeks kepuasan konsumen diperoleh dari total nilai weighted score (WS) dibagi skala maksimum yang digunakan (5) dan dikalikan dengan 100 $\%$. 


$$
\begin{aligned}
& W F_{i}=\frac{M I S_{i}}{\sum_{i=1}^{p} M I S_{i}} W S_{i}=W F_{i} \times M S S_{i} \\
& C S I=\frac{\sum_{i=1}^{p} W S_{i}}{H S} \times 100 \%
\end{aligned}
$$

Hasil perhitungan di atas dapat dilihat pada Tabel 7.

Tabel 7. Hasil Analisis Customer Satisfaction Index (CSI) pada Sayuran

\begin{tabular}{|c|c|c|c|c|}
\hline Atribut & MIS & WF & MSS & WS \\
\hline $\begin{array}{l}\text { Sayuran } \\
\text { higienis bebas } \\
\text { pestisida }\end{array}$ & 4,71 & 0,08 & 4,74 & 0,39 \\
\hline $\begin{array}{l}\text { Kesegaran } \\
\text { sayuran }\end{array}$ & 4,89 & 0,09 & 4,74 & 0,40 \\
\hline $\begin{array}{l}\text { Sayuran mulus } \\
\text { tanpa cacat } \\
\text { serangan hama }\end{array}$ & 4,49 & 0,08 & 4,6 & 0,36 \\
\hline $\begin{array}{l}\text { Sayuran tidak } \\
\text { rusak atau } \\
\text { busuk }\end{array}$ & 4,77 & 0,08 & 4,51 & 0,38 \\
\hline $\begin{array}{l}\text { Sayuran } \\
\text { memiliki rasa } \\
\text { yang enak }\end{array}$ & 4,51 & 0,08 & 4,54 & 0,36 \\
\hline Tekstur sayuran & 4,4 & 0,08 & 4,46 & 0,34 \\
\hline $\begin{array}{l}\text { Keasrian } \\
\text { sayuran }\end{array}$ & 4,26 & 0,07 & 4,4 & 0,33 \\
\hline $\begin{array}{l}\text { Kondisi fisik } \\
\text { sayuran }\end{array}$ & 4,57 & 0,08 & 4,51 & 0,36 \\
\hline $\begin{array}{l}\text { Fungsi kemasan } \\
\text { sayuran }\end{array}$ & 4,14 & 0,07 & 4,37 & 0,32 \\
\hline $\begin{array}{l}\text { Penataan } \\
\text { sayuran }\end{array}$ & 4,11 & 0,07 & 4,31 & 0,31 \\
\hline $\begin{array}{l}\text { Kerapian } \\
\text { kemasan }\end{array}$ & 4,17 & 0,07 & 4,4 & 0,32 \\
\hline $\begin{array}{l}\text { Kelayakan } \\
\text { Harga }\end{array}$ & 4,23 & 0,07 & 4,49 & 0,33 \\
\hline $\begin{array}{l}\text { Adanya promo } \\
\text { atau diskon }\end{array}$ & 4,06 & 0,07 & 3,31 & 0,23 \\
\hline TOTAL & $\mathbf{5 7 , 3}$ & 1,00 & $\mathbf{5 7 , 4}$ & $\mathbf{4 , 4 3}$ \\
\hline CSI & \multicolumn{4}{|c|}{$89 \%$} \\
\hline
\end{tabular}
Hidroponik

Tabel 7 menunjukkan bahwa hasil perhitungan CSI pada sayuran hidroponik memperoleh skor sebesar 89\%. Skor tersebut berada dalam suatu rentang skala $81 \%<\mathrm{CSI} \leq 100 \%$ yang berarti bahwa tingkat kepuasan konsumen responden termasuk dalam kategori sangat puas. Hasil perhitungan tersebut menyatakan bahwa konsumen merasa sangat puas terhadap kinerja yang dihasilkan oleh atribut-atribut yang melekat pada sayuran hidroponik Casa Farm, sehingga perlakuan yang perlu dilakukan adalah mempertahankannya.

Hasil perhitungan CSI hanya menunjukkan secara keseluruhan tingkat kepuasan konsumen responden terhadap atribut-atribut yang melekat pada sayuran hidroponik. Sementara untuk atribut mana yang dianggap puas dan kurang puas berdasarkan tingkat kepentingan dan tingkat kinerja oleh konsumen responden telah dibahas sebelumnya menggunakan metode IPA.

\section{KESIMPULAN DAN SARAN}

\section{Kesimpulan}

Berdasarkan hasil penelitian, diketahui bahwa pelanggan perempuan dengan rata-rata umur 40 tahun dan mayoritas bekerja sebagai ibu rumah tangga dan berdomisili di Kota Bandung merupakan karakteristik umum konsumen Casa Farm Hidroponik. Berdasarkan hasil perhitungan dan pengukuran, tingkat kepuasan konsumen skala rumah tangga terhadap atribut sayuran adalah sebesar 89\% (Sangat 
Puas), sedangkan atribut sayuran yang dianggap penting bagi konsumen ialah sayuran higienis bebas pestisida, kesegaran sayuran, sayuran mulus tanpa cacat serangan hama, sayuran tidak rusak atau busuk, sayuran memiliki rasa yang enak, dan kondisi fisik sayuran.

\section{Saran}

Berdasarkan hasil penelitian yang diperoleh, didapatkan beberapa saran yang direkomendasikan:

1. Sebaiknya memperhatikan kembali dan meningkatkan kinerja atributatribut yang nilai kinerjanya masih rendah bagi konsumen, diantaranya adalah keasrian sayuran, fungsi kemasan sayuran, penataan sayuran, kerapian kemasan, dan adanya promo atau diskon.

2. Tetap mempertahankan kinerja atribut-atribut yang dinilai konsumen penting dan sudah baik.

\section{DAFTAR PUSTAKA}

Al Amin, M. (2017). Klasifikasi Kelompok Umur Manusia Berdasarkan Analisis Dimensifraktal Box Counting Dari Citra Wajah Dengan Deteksi Tepi Canny. MATHunesa (Jurnal Ilmiah Matematika), 2(6).

Andilla, Y. (2013). Analisis sikap konsumen dalam membeli sayuran segar di pasar modern Bumi Serpong Damai (BSD) Tangerang Selatan.
Arbi, M. (2016). Kajian Keterkaitan Produksi, Perdagangan dan Konsumsi Sayuran Hidroponik untuk Meningkatkan Partisipasi Konsumsi di Kota Palembang. Agriekonomika, 5(1), 54-63.

Badan Ketahanan Pangan. (2019). Direktori Perkembangan Konsumsi Pangan. Jakarta: Badan Ketahanan Pangan Kementrian Pertanian.

Darmawan, D. (2017). Pengaruh Kemasan dan Harga Terhadap Keputusan Pembelian Produk Sayuran Hidroponik.

Dhameria, V., Ferdinand, A. T., \& Mudiantono, M. (2014). Analisis pengaruh keunikan desain kemasan produk, kondusivitas store environment, kualitas display produk terhadap keputusan pembelian impulsif (studi pada pasaraya Sri Ratu Pemuda Semarang) (Doctoral dissertation, Diponegoro University).

Hadianti, I., Noor, T. I., \& Yusuf, M. N. (2019). Persepsi Konsumen Terhadap Atribut Sayuran Hidroponik (Suatu Kasus Pada Konsumen Sayuran Hidroponik Saat Car Free Day (CFD) Kabupaten Ciamis). Jurnal Ilmiah Mahasiswa Agroinfo Galuh, 6(3), 470-480.

Haryoto. (2009). Bertanam Seledri Secara Hidroponik. Yogyakarta: Kanisius.

Juarwan, Imaddudin. (2013). Analisis Persepsi Konsumen Terhadap Atribut Sayuran Hidroponik. Bogor: Institut Pertanian Bogor.

Lingga, P. (2005). Hidroponik Bercocok Tanam Tanpa Tanah. Penebar Swadaya. Jakarata. 80 hal.

Mukhtar, S., \& Nurif, M. (2015). Peranan packaging dalam meningkatkan hasil produksi terhadap konsumen. Jurnal Sosial Humaniora (JSH), 8(2), 181-191. 
Pamartha, D. A., \& E. (2016). Pengaruh Atribut Produk Terhadap Preferensi Konsumen Dan Keputusan Pembelian Kartu Seluler Simpati (Survei Pada Masyarakat Desa Wonosari, Kecamatan Pagu, Kabupaten Kediri Yang Membeli Kartu Seluler Simpati). Jurnal Administrasi Bisnis, 38(1), 14-20.

Purbajanti, Endang Dwi, dkk. 2017. Hidroponik Bertanam tanpa Tanah.

Rizkiansah, T., Kurniati, D., \& Imelda, I. (2018). Analisis Faktor-Faktor Pribadi Dan Psikologi Pada Proses Keputusan Pembelian Sayuran Hidroponik di Kota Pontianak (Studi Kasus Merek Sayok Kite). Jurnal Sains Mahasiswa Pertanian, $7(2)$.

Savira, R. D., \& Prihtanti, T. M. (2019). Analisa Permintaan Sayuran Hidroponik Di Pt. Hidroponik Agrofarm Bandungan. Agrilan: Jurnal Agribisnis Kepulauan, 7(2), 164-180.

Setyaningrum, H. D., \& Saparinto, C. (2012). Panen sayur secara rutin di lahan sempit. Penebar Swadaya Grup.
Siregar, H. M. (2019). Analisis Tingkat Kepuasan Konsumen Terhadap Sayuran Organik (Doctoral dissertation).

Solomon, Michael, (2004), Consumer Behavior: Buying, Having, and Being. Sixth Edition. Person Education International, New Jarsey

Suhardi. (2016). Pengantar Ekonomi Mikro. Yogyakarta: Penerbit Gava Media.

Supriyanto, Achmad Sani. dan Masyhuri Machfudz. (2010). Metodologi Riset: Manajemen Sumberdaya Manusia. Malang: UIN-Maliki Press.

Tandiono, C. T. (2018). Fasilitas Eduwisata Tanaman Hidroponik di Malang. Dimensi Arsitektur Petra, 6(1), 857-864.

Yasmin, T., Prastiwi, W. D., \& Handayani, M. (2017). Preferensi Konsumen Sayuran Hidroponik Agrofarm Bandungan Kabupaten Semarang. Agrisocionomics, 1(1), 1-94. 